\title{
Foraminifera of the Eptahorion Formation (early Oligocene) of the Mesohellenic Basin, northern Greece
}

\author{
ROBERTO BARBIERI \\ Agip SpA, \\ SGEL Servizio Studi Geologici \\ P.O. Box 12069 , \\ 20120 Milano, Italy
}

\begin{abstract}
Planktonic and benthic foraminifera from the type area of the early Oligocene Eptahorion Formation (Mesohellenic Basin, northern Greece) have been ranged and partly described and figured. Altogether, about 130 taxa were identified. According to the current age assignments, the formation is attributable to Blow's Zones P20 and P21. The record of benthic palaeoecologic indices has thrown light on bathymetric history of the formation. The deposition of the whole sequence, after the initial transgressive phase, occured in a marine, relatively deep environment. Palaeontologic evidence indicates few changes, ranging from the epibathyal to the outer neritic bathymetric domain. J. Micropalaeontol., 11 (1): 73-84, June 1992.
\end{abstract}

\section{INTRODUCTION}

The Oligocene-Miocene succession of the Mesohellenic Basin has received little attention in terms of detailed biostratigraphic investigations. As recently described and named by Ori et al.(1990) during their regional study of the area, the Oligocene and early Miocene rocks of the northern Mesohellenic Basin are wholly represented by four main units, from the base to the top they are the Eptahorion Formation, the Taliaros Formation, the Voion Formation and the Pendalofos Formation. A detailed examination of the biostratigraphy and palaeoecology of the first unit by means of foraminifera is the subject of this study.

\section{PREVIOUS STRATIGRAPHIC WORK}

Brunn (1956) described in detail the formation ("Marnes d'Eptakhorion") in its type area, around the village of Eptahorion. He referred the unit to the Stampian on the basis of the recovery of stratigraphically significant molluscan fauna. Desprairies (1979) described the stratigraphy and sedimentology of the formation ("Formation d'Eptakhorion") accepting the age of the unit according to the biostratigraphic data of Brunn. He again correlated the formation with the "Marnes de l'Arakhtos" and the "Gres d'Anemorakhi", of the Internal Ionian Zone (western tectonic zone of the Hellenids), without defining their chronostratigraphic limits or stratigraphic rank. In the Ionian Zone, Bizon \& Bizon (in IGRS-IFP, 1966) described poorly fossiliferous, flysch deposits lithologically and chronologically comparable to those of the Mesohellenic Basin. In recent years, papers dealing with the biostratigraphic evolution of the Mesohellenic Oligocene have been published by Soliman \& Zygojannis (1979a and b, 1980). The basic material of their study were some sections cropping out in the southern area of the Oligocene basin (Meteora region). Data from the north (Eptahorion area) are limited to some planktonic and benthic foraminiferal lists obtained from unknown stratigraphic locations. Listed planktonic species are Globigerina ampliapertura,G. angulisuturalis, G.ciperoensis,G. sellii and Globorotalia opima. Marginal marine facies (neritic and littoral) referred to the Eptahorion Formation are described from the Grevena Basin and the northern part of the Thessalia Basin, both located southeast of the type area and chronologically assigned to the late Oligocene (Steininger et al. (1985). More recently, Ori et al.(1990) discussed in detail the Oligocene-early Miocene stratigraphy of the northern Mesohellenic Basin. The biostratigraphic and palaeoenvironmental framework was based on foraminiferal data and on relationships between lithofacies and biofacies.

\section{AREA OF INVESTIGATION, LITHOLOGY AND DEFINITION}

The Eptahorion Formation extends over a large geographic area in north-western Greece. It typically outcrops in the area around the village of Eptahorion, western Macedonia, in a series of well exposed hillsides. The extent of the formation in the study area is shown in Fig. 1.

The formation unconformably overlies the ophiolites of the Subpelagonian Zone. The contact of the formation with the overlying Taliaros Formation (late Oligocene), mainly sandstones and arenaceous shales, is marked by an unconformity. In its type area the unit consists of a generalized fining upward sequence, more than $\mathbf{1 1 0 0}$ meters thick (Ori et al., 1990), with mainly arenaceous conglomerates at the base totally devoid of macro and microfossils. The formation grades upward into sandstones interbedded with silty marls and shales with relatively rich foraminiferal contents. The fine-grained interbeds in the lowest part of the formation contain a few mollusc and ostracod-rich horizons.

\section{MATERIAL AND METHODS}

One continuous section, almost totally exposed within the area of investigation, with minor portions covered by vegetation, was measured (Fig. 2). Planktonic and benthic foraminifera were studied from 38 samples collected in the sediments 


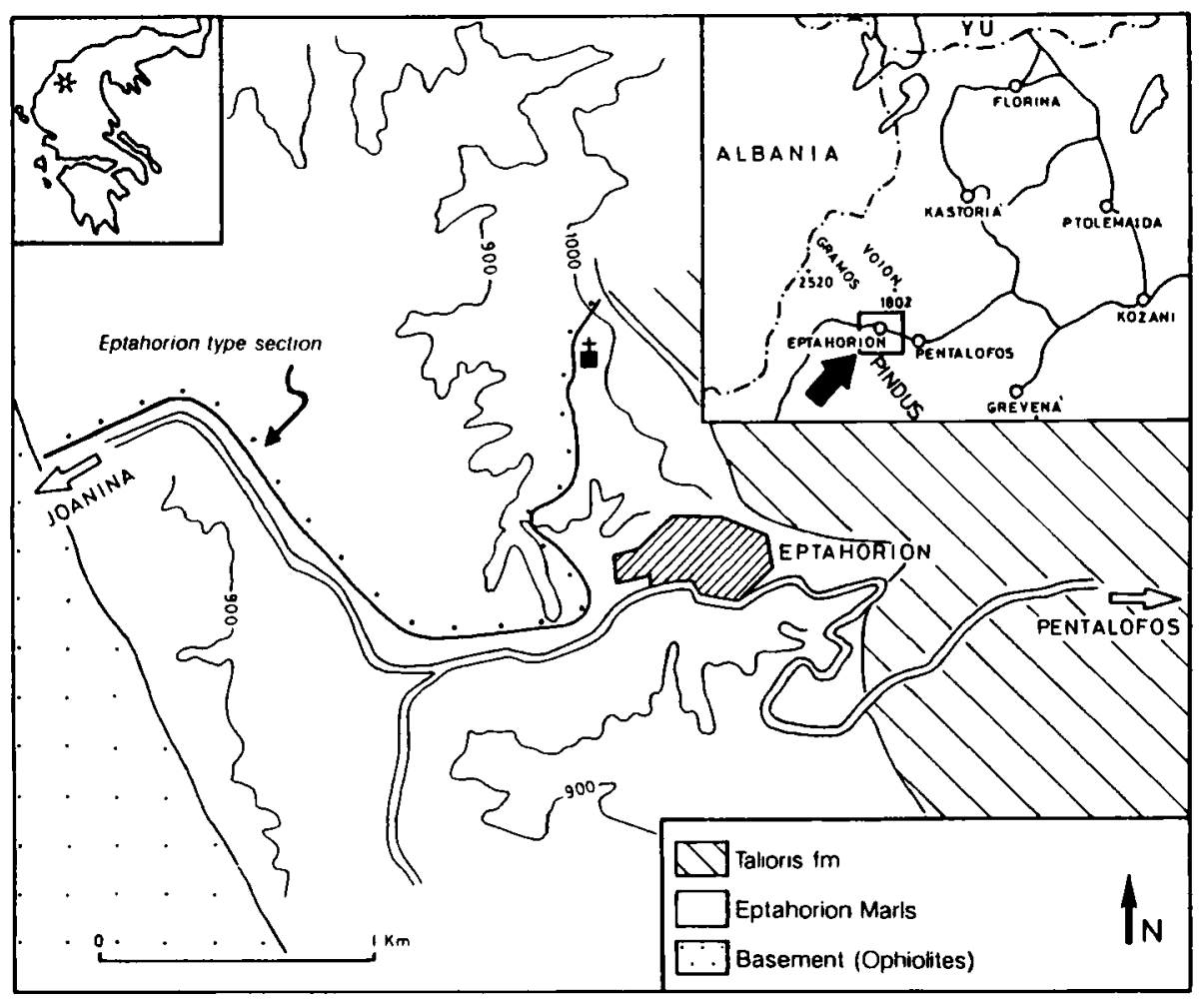

Fig. 1. Locality and geologic map of the Eptahorion area, northern Mesohellenic Basin, and location of the studied section (geologic data after Ori et al, 1990).

exposed along the road in the hillsides that run westward from the village of Eptahorion (Fig. 1). Samples were collected at intervals of about 50-100 metres within the lower portion of the section, and at intervals of 5-20 metres in the middle and upper parts.

Samples were crushed and disaggregated by hydrogen peroxide solution $(30 \%)$ or dimethylbenzilammonium chloride solution (10\%), from at least one hour to 24 hours, and washed with distilled water through a 200 mesh sieve.

\section{AGE AND ZONE ASSIGNMENTS}

Zones are assigned using both the classic zonal scheme established by Blow (1969) and that more recently proposed by Bolli \& Saunders (1985). The last two authors mainly used the Oligocene zonal definitions as originally defined by Bolli (1957).

Zones recognized are defined as follows: Globorotalia opima opima Zone represents a taxon-range zone and it is therefore defined by the range of the zonal marker (Bolli and Saunders, 1985). Zone P21 has its base defined by the first occurrence of Globigerina angulisuturalis (Blow, 1969). Thus, according to the original definition, the lower part of the G.opima opima Zone, which corresponds to the interval immediately below the first occurrence of $G$. angulisuturalis, belongs to Zone P20.

\section{PLANKTONIC FORAMINIFERA}

A total of 33 planktonic taxa were identified, some of them having stratigraphic significance. Their distribution and abundance is shown in Fig. 3. Samples collected from the lower part of the section, a total of about 300 metres, are totally devoid of planktonic species. Almost all the fossiliferous samples investigated contain deformed or crushed specimens, occasionally pyritized. Within some intervals planktonic specimens are rare and poorly preserved ( e. g. from samples 31 to 34 ). But the interval including the boundary between Zones $\mathrm{P} 20$ and P21 (from samples 8 to 18 ) yielded relatively diverse and well preserved assemblages. The four main genera representing most of the recorded taxa are Catapsydrax, Globigerina, Globoquadrina and Paragloborotalia.

The generalized morphologic affinity within the planktonic foraminiferal population is due to a peculiarcharacteristic of theOligocene assemblages, namely a worldwide dominance by small pentacamerate globigerinids and small to large tetracamerate globigerinids (discussed in detail by Stainforth, 1975 and Stainforth \& Lamb, 1981). The relatively low diversity between temperate and tropical areas in the Oligocene oceanic plankton assemblages (Kennett, 1978; Sancetta,

1979) is well known.

According to the stratigraphic ranges of the planktonic foraminifera provided by Baumann (1970), Blow (1969), Bolli (1966), Bolli \& Saunders (1985), Stainforth et al (1975) and Stainforth \& Lamb (1981), the assemblages of the Eptahorion Formation range from the upper part of Zone P20 to Zone P21 of Blow's zonal scheme. With respect to this relatively short stratigraphic interval, most of the recorded taxa are long ranging.

The first occurrence of Globigerina angulisuturalis provides an excellent world wide datum used by a number of authors to define the base of their Globorotalia opima Zone (e. g. Baumann, 1970; Stainforth \& Lamb, 1981). The boundary between Zone P20 and P21 is placed in the present section with sample 10, on the basis of the appearance of G.angulisuturalis. The first record of Paragloborotalia opima occurs in the same sample and is believed to be non evolutionary. There is no trace, indeed, of any overlapping range between Globigerina ampliapertura and P.opima, which would correspond to the lowest interval of Globorotalia opima opima taxon-range Zone. The concurrence of the above two taxa is widely reported in the literature, both in low latitude (Blow, 1969; Stainforth et al. (1975) and in the Tethys area (Baumann, 1970; Molina, 1979). Nevertheless, this point is still puzzling and several authors reject the assumed overlap (Beckmann et al. 1981; Bolli and Saunders, 1985).

LateOligocene-Miocenetaxa, such as "Globorotalia" siakensis and Globoquadrina dehiscens praedehiscens, whose appearance is usually placed within Zones P21/P22, are also present. These two species generally exhibit a close first occurrence, as confirmed by the Eptahorion assemblages, with partial overlap 


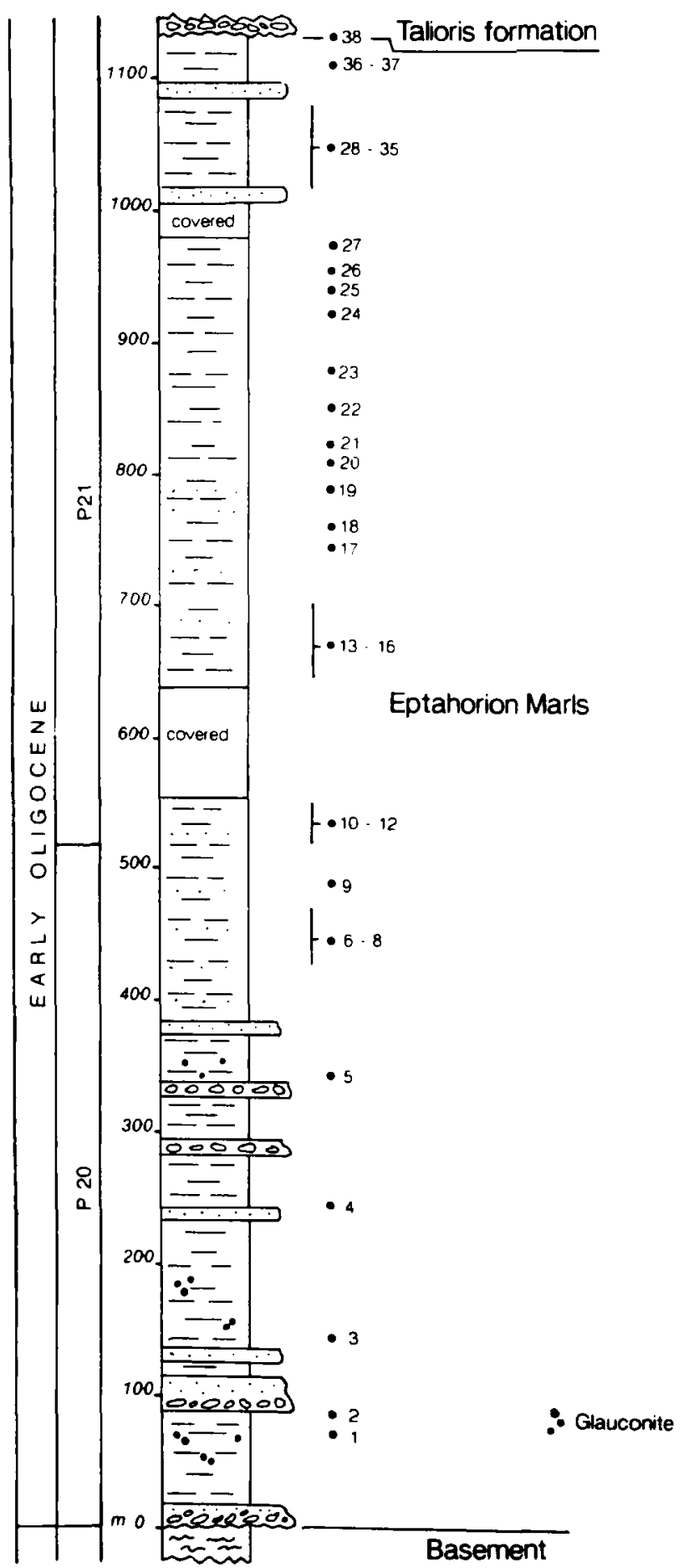

Fig. 2. Stratigraphic columnar section of the Eptahorion Formation, northern Mesohellenic Basin.

of the P. opima range.

Finally, the P.opima appearance is here believed to be a "local late appearance", presumably due to sedimentary factors rather than to ecologic ones.

G. ampliapertura represents an excellent marker to identify in the broadest term the lower part of the Oligocene. In the studied material no specimens of this widespread taxon were recovered. Specimens figured as G. ampliapertura by Soliman \& Zygojannis (1980, pl. 24, figs. 2-3) clearly differ from the Bolli's type figures; thus, they are devoid of the equivalent biostratigraphic meaning.

No main discrepancies within the planktonic foraminiferal distribution are noted, with the remarkable exception of Globoquadrina tapuriensis. This rare taxon has been recorded in just two samples from Zone P21. It is seldom given because of the difficulty in keeping the subspecies separate from the closely related G. tripartita tripartita. Nevertheless, its distribution exhibits an extinction level which usually does not exceed Zone P20. Such shifting upward of the range of $G$. tapuriensis has already been described in the Hungarian Oligocene (Sztrakos, 1979). The range of the other significant species is similar, with minor differences, to those usually reported in the literature.

Despite the lack of foraminiferal records in the lower part of the section, one should be aware that there is no evidence for these beds in a zone older than P20. On the contrary, the early occurrence of taxa that typify Zones P20/P21, close to the G. angulisuturalis datum, provides some confidence in the attribution of the whole lower section to Zone P20.

There is no evidence, within the planktonic record, of any remarkable change in temperature. During the time interval of the deposition of formation planktonic foraminifera maintained their warm water characteristics. According to Keller (1983) a major cooling episode, related to an eustatic sea level drop (Haq et al.1987) occurred at the P20/P21 boundary.

\section{BENTHIC FORAMINIFERA}

The marly and shaly samples collected in the Eptahorion section contain a generally diverse benthic foraminiferal fauna. These assemblages usually outnumber the planktonics, by $50 \%$ to more than $95 \%$. The section may be divided into four palaeobathymetric zones where 92 taxa have been recorded and ranged (figure 4). A number of long ranging, frequently occuring species, such as Guttulina communis, most of the nodosariids and lenticulinids, have not been listed. Although benthic foraminifera are generally more preservable and resistant to mechanical breakage than planktonics (Douglas, 1973), the benthic assemblages constantly contain crushed and deformed specimens. The assemblages, as well as any single taxon, have limited biostratigraphic value, most of the common taxa exhibiting wide stratigraphic range.

Species reported worldwide from the Oligocene strata include Spiroplectammina clotho, Osangularia pteromphalia,Uvigerina cocoaensis group, U. eocaena, U.alazanensis, Planulina marialana, Bulimina palmerae, Anomalinoides ammophilus, Baggina valvulineriaformis, Almaena hieroglyphica, Heterolepa costata.

A few species, generally the rare ones, can be useful in dating sediments. The occurrence of Bolivina semistriata in the lower part of Zone P21 should be emphasized. This taxon seems to reach its stratigraphic top within the Rupelian (early Oligocene) in the northern Alps (Lindenberg, 1965; Hofmann, 1967). The uppermost beds of the formation show the appearance of Anomalinoides maioricensis, which is restricted to the upper Oligocene and Miocene strata in northern Italy (Agip, 1982). The coarsely perforated Cibicidoides havanensis 


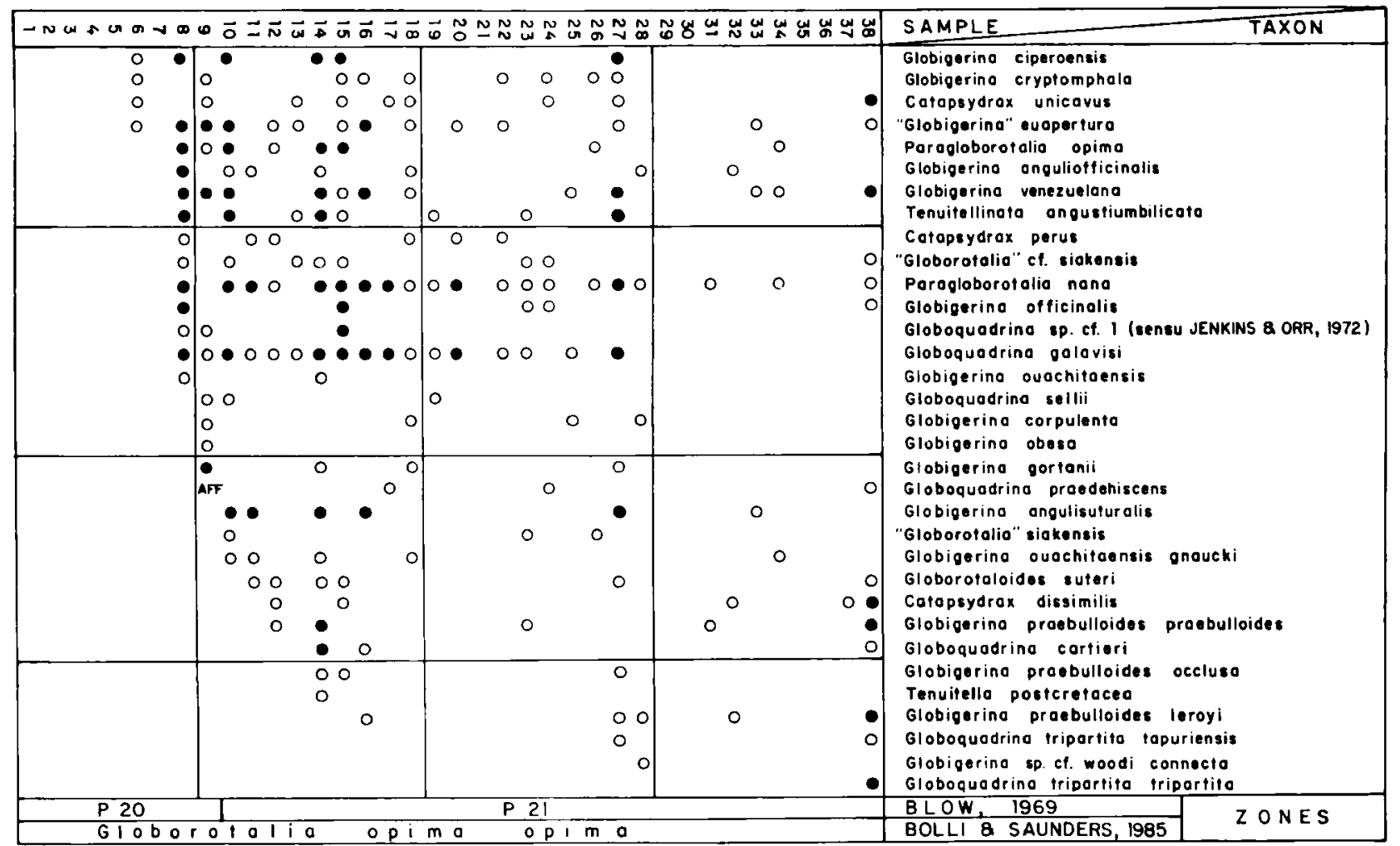

Fig. 3. Stratigraphic ranges of planktonic foraminifera from the Eptahorion Formation.

could exhibit significant stratigrafic value, Schnitker (1979) and Miller (1983) gave the range this species up to the late Oligocene in the Bay of Biscay (Zones P21/P22).

During the Late Palaeogene, the deep-sea benthic foraminifera seem to exhibit a cosmopolitan distribution (Berggren \& Phillips, 1971; Douglas, 1973; Proto Decima \& Bolli, 1978; Thomas, 1985) with some remarkable worldwide faunal changes. The comparison of the studied assemblages with time equivalent Caribbean benthic population is difficult to account for reasonable limits in confidence of the taxonomic identification. Nevertheless, this comparison suggests some affinities: at least 15 stratigraphically significant species are common to both these provinces, they are Anomalinoides alazanensis, A. pseudogrosserugosus, Bulimina palmerae, B. rostrata (=B.alazanensis), Gyroidinoides subangulatus, Gyroidina soldanii, Heterolepa costata, H.praecincta, Cibicidoides pseudoungerianus C.pachyderma, Planulina marialana ,P.renzi, Uvigerina havanensis, U.jacksonensis.

\section{PALAEOBATHYMETRY}

The Eptahorion section has been divided into four zones based on foraminiferal abundance and palaeobathymetric inference (Fig. 4).

Samples from 1 to 5 identify the zone A. The interval is almost totally barren, a few unidentifiable foraminiferal specimens, crushed and spathized, were collected from sample 1. Molluscan and ostracod shells and fragments were collected from the same level of sample 5 (Colalongo, personal communication, recognized an oligotipic, brackish ostracod fauna). Abundant glauconite and pyrite are mineral accessories constituents. Despite the extremely poor fossil record, sedimentological evidence suggests a proximal deltaic, shallow water environment. (Desprairies, 1979; Ori et al, 1990).

Zone $B$ ranges from samples 6 to 28 and includes the boundary between Blow's Zones P20 and P21. Benthics are particularly abundant and diverse. The lower boundary of the zone $B$ is based on the first, sudden foraminiferal recovery. The dominant taxa are Spiroplectammina carinata, Dorothia beloides, uvigerinids, Globocassidulinaglobosa/subglobosagroup, Melonis affinis, Bulimina palmerae, Almaena hieroglyphica, gyroidinoids. In most of these samples a significant number of costate uvigerinids is recorded, they include Uvigerina cocoaensis group, U.gallowayi and U. eocaena. This group, well known as an excellent bathymetric marker, is generally assigned to the upper epibathyal environment (Pflum \& Frerichs, 1976; Pujos-Lamy, 1984; Boersma, 1986). Direct relationship between ornamentation and depth was suggested by Sztrakos (1983) on the basis of the Hungarian costate uvigerinids. The Eptahorion material contains comparable results: predominance of costate specimens within zone B and, by contrast, weakly costate specimens of shallower conditions, in the overlying zone $\mathrm{C}$. It is probable that Uvigerina coconensis subspecies (cocoaensis and jacksonensis, undivided in this study) represent a cline (ecophenotipic variants). Together with the listed taxa, environmentally diagnostic species include Valvulineria palmarealensis, Sigmoilinita tenuis and Bulimina rostrata.

The prevailing palaeobathymetric interpretation of the benthic assemblages,suggests epibathyal conditions, with water depth not exceeding 500-700 meters. The very rare 
Foraminifera of the Eptahorion Formation

\begin{tabular}{|c|c|c|c|c|c|c|c|}
\hline - Nwrug & & 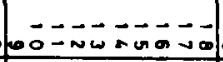 & $-\infty$ & 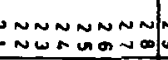 & No & 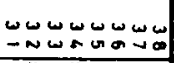 & 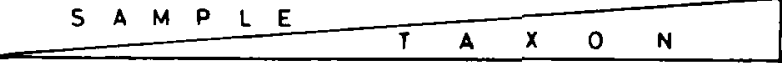 \\
\hline & \begin{tabular}{ll|}
$x$ & $x$ \\
$x$ & $x$ \\
$x$ & \\
$x$ & $x$ \\
$x$ & \\
$x$ & \\
$x$ & $x$ \\
$x$ & $x$ \\
$x$ & $x$ \\
$x$ & $x$ \\
\end{tabular} & $\left|\begin{array}{llllll}x & x & x & x & x & x \\
x & & x & & x & x \\
x & x & x & x & x & \\
x & x & x & x & x & x \\
x & x & x & x & x\end{array}\right|$ & $\begin{array}{ll}x \\
x \\
x & x \\
x & x\end{array}$ & $\begin{array}{l}\times \times \times \\
\times \times \times \times \times \times \times \\
\times \times \times \times \times \\
\times \times \times\end{array}$ & $\left.\right|_{x} ^{x}$ & 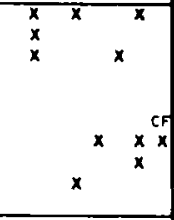 & 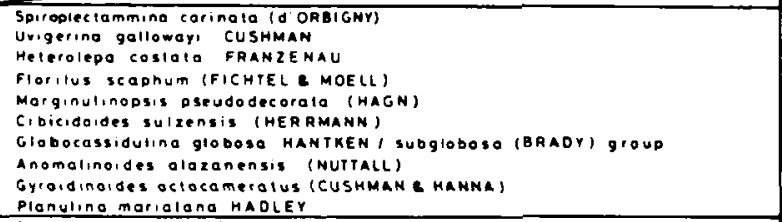 \\
\hline & 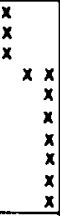 & 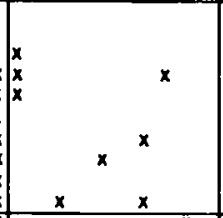 & $x$ & $\begin{array}{r}x \times x \times x \\
x \times x\end{array}$ & & $\begin{array}{r}x \\
x^{\times} \times \\
\end{array}$ & 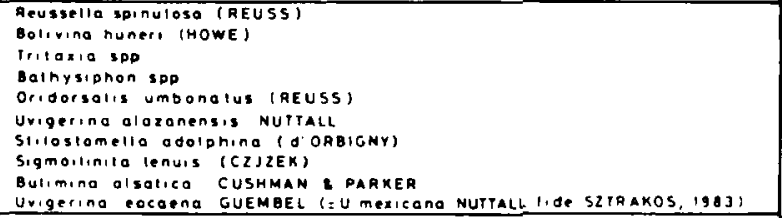 \\
\hline & $\begin{array}{l}\mathbf{x} \\
\mathbf{x} \\
\mathbf{x} \\
\mathbf{x} \\
\mathbf{x} \\
\mathbf{x} \\
\mathbf{x} \\
\mathbf{x} \\
\mathbf{x}\end{array}$ & 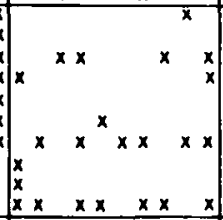 & $x$ & 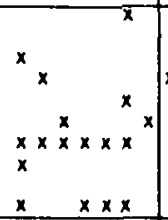 & $x$ & ${ }_{x}^{x} x^{x} x$ & 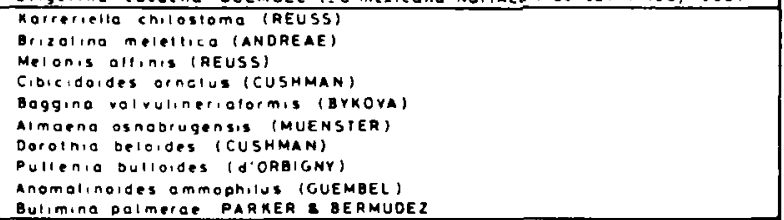 \\
\hline & & 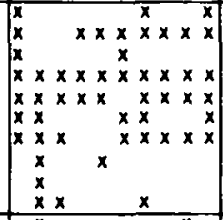 & $\mid \begin{array}{l}x \\
x \\
x \\
x\end{array}$ & 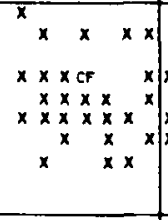 & $\mid \begin{array}{l}x \\
x \\
x\end{array}$ & 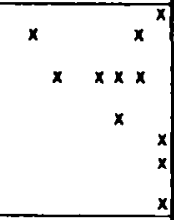 & 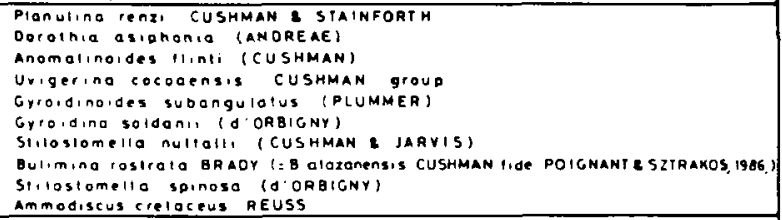 \\
\hline & & 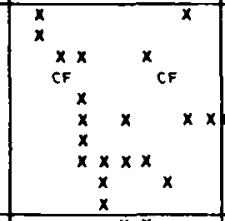 & $x$ & $\begin{array}{cccc}x & x & x & x \\
x & x & \\
& x & x \\
x \times x & x & x \\
x & x & \\
x & x & x\end{array}$ & 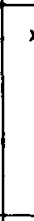 & $\begin{array}{r}x \times x \\
x \in x \\
x \in x\end{array}$ & 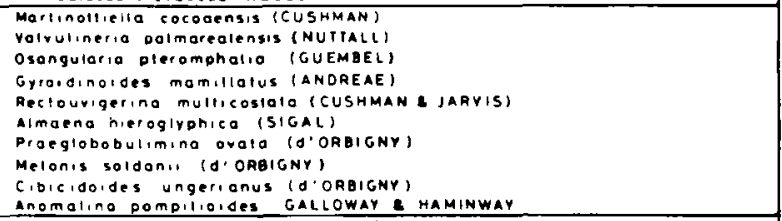 \\
\hline & & \begin{tabular}{|c|}
$x$ \\
$x$ \\
$x$ \\
$x$ \\
$x$ \\
$x$ \\
$x$ \\
$x$ \\
$x$ \\
$x$ \\
\end{tabular} & & $\times$ & & $\begin{array}{lll}x & x \\
x & & \\
& & \end{array}$ & 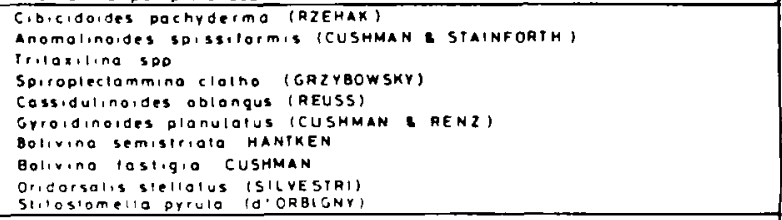 \\
\hline & & \begin{tabular}{r|}
$x$ \\
$x$ \\
$x$ \\
$x$ \\
$x$ \\
\end{tabular} & $\begin{array}{ll}x & x \\
x \\
x \\
x\end{array}$ & 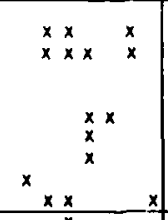 & & $x \times$ & 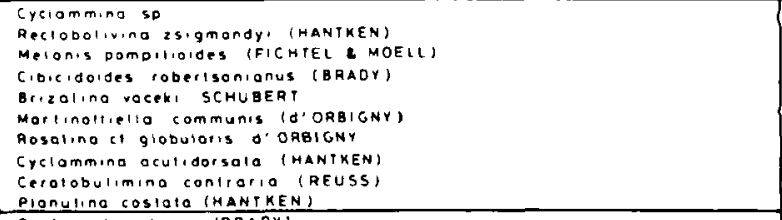 \\
\hline & & & & 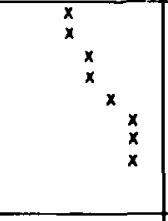 & & $x$ & 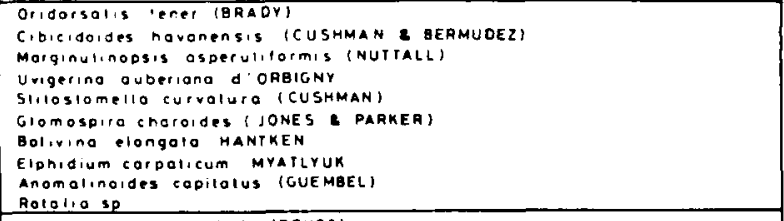 \\
\hline & & & & & & 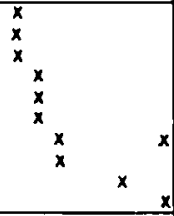 & 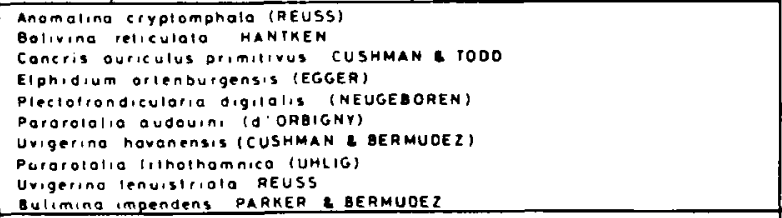 \\
\hline & & & & & & & $\begin{array}{l}\text { Reophax sp } \\
\text { Heterolepo praecincla (KAGRER) } \\
\text { Anomalinoides maioricensis (COLOM) }\end{array}$ \\
\hline$P 20$ & & & & 21 & & & Biostratigraphic zones (BLOW.1969) \\
\hline A & & B & & & & C & $p a \mid a e o b a t h y m e t r i c$ \\
\hline
\end{tabular}

Fig. 4. Stratigraphic ranges of benthic foraminifera from the Eptahorion Formation. 
recovery of a number of taxa commonly widespread in the Oligocene bathyal strata, such as Glomospira spp., Cyclammina spp., Melonis spp. and Cibicidoides havanensis, confirm this interpretation. Assemblages comparable with those described from zone B are reported by Sztrakos (1979) from theepibathyal sediments of the Hungarian Oligocene.

Zone $\mathrm{C}$ extends from sample 28 to 37 . It is assigned to the upper epibathyal toward outer neritic environment. This interval is characterized by a sharp decrease in the species number. Dominant taxa of the underlying zone are still present, but reduced in number. New taxa rarely occur and include several Pararotalia species, Elphidium carpaticum, E. ortenburgensis, Cancris auriculus primitivus, Uvigerina tenuistriata. It is believed that most of these species represent displaced specimens from shallower water. Other relatively significant taxa, already listed in the previous zone, are Uvigerina cocoaensis group, Almaena hieroglyphica, Spiroplectammina carinata. The recovery of U.tenuistriata has some interest. Sztrakos (1983) assigned bathymetric significance to this weakly costate uvigerinid, confining it mainly within the neritic domain.

A single sample, 38, located at the top of the section, is attributed to zone D. It clearly reflects deeper water. The abundant assemblage is dominated by planktonic foraminifera $(80 \%)$. Benthics are particularly diverse and large number of taxa of the underlying zone $B$ reoccurs here. Bathymetric index species include Melonis affinis, Bulimina palmerae, $B$. rostrata, Cibicidoides robertsonianus. The latter species, widely reported by authors as a lower epibathyal taxon, has its upper depth limit around 600 meters (Wright, 1978; van Morkhoven et al., 1986).

The moderate deepening and shallowing evidenced by the benthonic foraminifera during the environmental evolution of the Eptahorion Formation, is usually linked with associated lithologic changes. Particulary during the major, dramatic change, from zones $A$ and $B$, variation in the sedimenation occurred. Although the evidence of relation between sediment and benthic foraminiferal abundance - as pointed out, for instance, by Winkler (1983) in the turbidite deposits - the changes in paleodepth appear to be the major factor controlling faunal change mechanisms in the Eptahorion sediments.

Further faunal considerations can be summarized in the following points :

a) the plankton/benthos ratio generally gives to the benthonics a strong predominance. On the contrary, recent deep-sea sediments of the Mediterranean contain generally planktonic foraminifera in excess of 95\% (Cita \& Zocchi, 1978).

b) high number of foraminiferal shells, mainly planktonics, broken or deformed, are constantly present. c) all the investigated samples contain very small amount of species displaced from shallow water.

The joint occurrence of points a) and b) should be simply due to the fact that benthic are more resistant to mechanical breakage than planktonic specimens during post mortem transport and accumulation. Moreover, the lack of species clearly reworked excludes extraformational contaminations.

\section{CONCLUSIONS}

The detailed observations of the foraminifera in the Eptahorion Formation lead to assign the sequence within the total range of Paragloborotalia opima, except for the lower portion, in which age-diagnostic foraminifera are virtually missing. An attribution to Zone P20 is, therefore, indirectly derived from the zonal attribution of the overlying strata. A finer delineation of the zonation is not possible from the data at hand.

The first occurrence of Globigerina angulisuturalis in the middle part of the formation allows the recognition of Zone P21, providing a reliable worldwide correlation datum.

Above the palaeocological Zone A, signalling probable inadequate conditions of depth and salinity for foraminiferal life, there is no evidence of marked or dramatic bathymetric changes. The minor differences recorded range within the lower epibathyal-outer neritic interval.

\section{SYSTEMATIC DESCRIPTIONS}

Order Foraminiferida Richwald, 1830

Superfamily Globigerinacea Carpenter, Parker \& Jones, 1862

Family Globigerinidae Carpenter, Parker \& Jones, 1862 Genus Catapsydrax Bolli, Loeblich \& Tappan, 1957

Catapsydrax dissimilis (Cushman \& Bermudez, 1937) 1937 Globigerina dissimilis Cushman \& Bermudez; p. 25, pl. 3 , figs 4-6.

Catapsydrax perus (Todd, 1957)

(Pl. 1, fig. 10)

1957 Globigerina pera Todd: p. 301, pl. 70, figs. 10-11.

Catapsydrax unicavus Bolli, Loeblich and Tappan, 1957 1957 Catapsydrax unicaous Bolli, Loeblich and Tappan: p. 37, pl. 7, fig. 9.

Genus Globigerina d'Orbigny, 1826

Globigerina anguliofficinalis Blow, 1969

1969 Globigerina ciperoensis anguliofficinalis Blow: pp. 379-380, pl. 11, figs. 1-5.

Globigerina angulisuturalis Bolli, 1957

(Pl. 2, fig. 1)

1957 Globigerina ciperoensis angulisuturalis Bolli: p. 109, pl. 22, fig. 11.

\section{Explanation of Plate 1 \\ (all figures are $x 115$ )}

Figs. 1-3. Globoquadrina cartieri (Chaproniere). Ventral, peripheral and dorsal views. Zone P21.

Figs. 4-6. "Globigerina" euapertura (Jenkins). Ventral, peripheral and dorsal views. Zone P20.

Figs. 7-9. "Globorotalia" sp. cf. siakensis (Le Roy). Ventral, peripheral and dorsal views. Zone P20.

Fig. 10. Catapsydrax perus (Todd). Ventral view. Zone P20.

Fig. 11. Globoquadrina praedehiscens Blow \& Banner. Ventral view. Zone P21. 

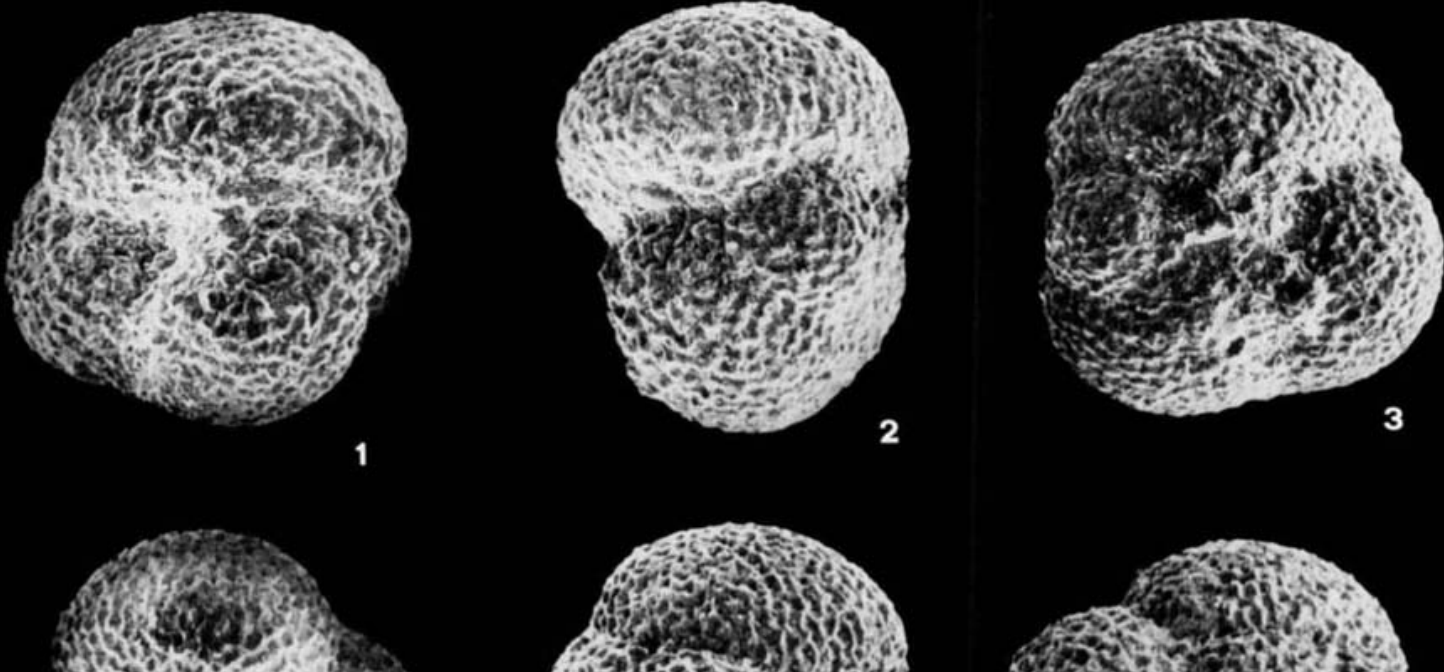

A. 58,50

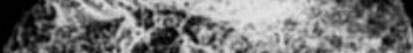

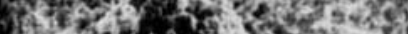

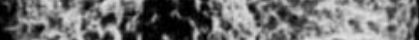

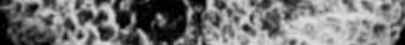

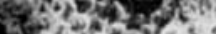

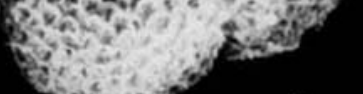

4
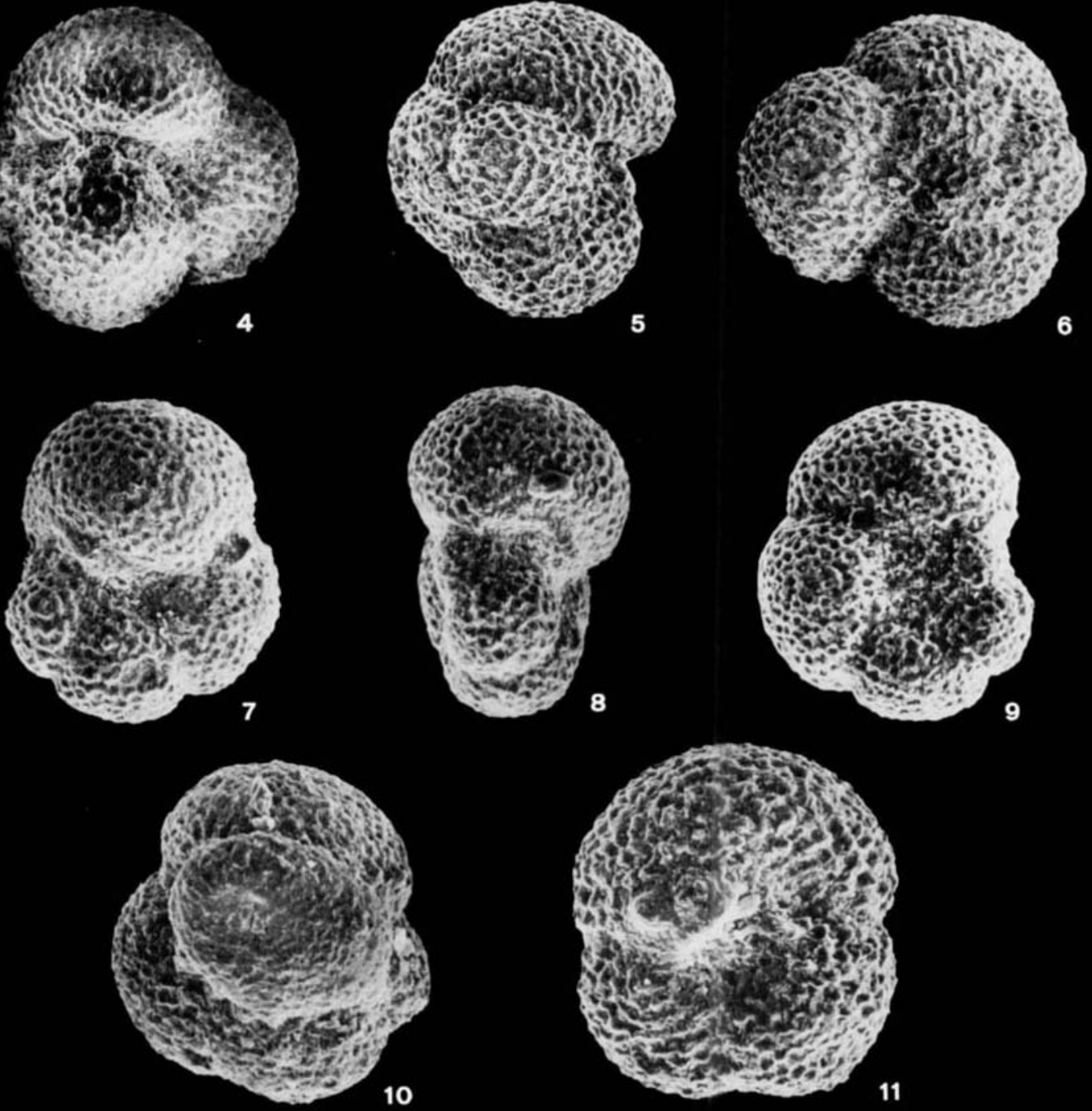
Globigerina ciperoensis Bolli, 1954

1954 Globigerina ciperoensis ciperoensis Bolli: pp. 1-3, figs. 3-4.

Globigerina corpulenta Subbotina, 1953

(Pl. 2, figs. 10-11)

1953 Globigerina corpulenta Subbotina: p. 76, pl. 9, figs. 5-7.

Globigerina cryptomphala Glaessner, 1937

1937 Globigerina bulloides d'Orbigny var. cryptomphala Glaessner: p. 29, pl. 1, fig. 1.

"Globigerina" euapertura Jenkins, 1960

(Pl. 1, figs. 4-6)

1960 Globigerina euapertura Jenkins: p. 351, pl. 1, fig. 8.

Remarks. The species represents a conspiquous element within the Eptahorion microfauna, with typical and abundant specimens. According to Chapronière (1981) "Globigerina" prasaepis Blow is a junior synonym of G. euapertura.

Globigerina gortanii (Borsetti, 1959)

(Pl. 2, fig. 6)

1959 Catapsydrax gortanii Borsetti: p. 205, pl. 1, fig. 1.

Remarks. Few specimens referable to Globigerina praeturritilina Blow \& Banner (plate 2, fig. 5), occurring in the lower part of the section, are located under the heading of G. gortanii.

Globigerina obesa (Bolli, 1957)

1957 Globorotalia obesa Bolli: p. 119, pl. 29, figs. 2-3.

Globigerina officinalis Subbotina, 1953

(P1. 2, fig. 9)

1953 Globigerina officinalis Subbotina: p. 78, pl. 11, figs. 1-7.

Globigerina ouachitaensis ouachitaensis

Howe \& Wallace, 1932

1932 Globigerina ouachitaensis Howe \& Wallace: p. 74, pl. 10, fig. 7.

Globigerina ouachitaensis gnaucki Blow \& Banner, 1962 1962 Globigerina ouachitaensis gnaucki Blow \& Banner: p.91, pl. 9, figs. L-N.

Remarks. Typical but rare specimens referable to this subspecies are recorded from several samples within the lower part of Zone P21.

Globigerina praebulloides leroyi Blow \& Banner, 1962 1962 Globigerina praebulloides leroyi Blow \& Banner: p. 93, pl. 9 , figs. R-T.
Globigerina praebulloides occlusa Blow \& Banner, 1962 1962 Globigerina praebulloides occlusa Blow \& Banner: p. 93,pl. 9, figs. U-W.

Globigerina praebulloides praebulloides Blow, 1959 1959 Globigerina praebulloides Blow: p. 180, pl. 8, fig. 47. Remarks. Although all the praebulloides subspecies are easily identifiable, the presence of intermediate specimens is common, and it makes their abundance higher than plotted in the distribution chart. They always represent a conspiquous element within the assemblage of small globigerinids.

Globigerina venezuelana Hedberg, 1937

1937 Globigerina venezuelana Hedberg: p. 681, pl. 92, fig. 7.

Globigerina sp. cf. woodi connecta Jenkins, 1964 1964 cf. Globigerina woodi connecta Jenkins: p. 72, fig. 1. Remarks. Only one specimen of this taxon is recorded from the sample 28 .

Genus Globoquadrina Finlay, 1947 Globoquadrina cartieri (Chapronière, 1981) (Pl. 1, figs. 1-3)

1981 Subbotina cartieri Chapronière: pp. 114-116, figs. 5 A-E. Remarks. Specimens referable to Globoquadrina cartieri occur from several samples, they strictly correspond to the type figures and extend the geographic distribution of the taxon to the Tethys area. G. cartieri and Globoquadrina pseudovenezuelana seem morphologically close, both taxa show typical tooth-like lip. Nevertheless, no stratigraphic overlap is recognized, the former being a prevailing late Oligocene taxon, while the latter ranging up to the early Oligocene.

Globoquadrina galavisi (Bermudez, 1960)

1960 Globigerina galavisi Bermudez: p. 1183, pl. 5, figs. 1-3.

Remarks. Blow (1969) reillustrated the holotype (pl. 16, figs 4 , $5)$.

Globoquadrina praedehiscens Blow \& Banner, 1962 (Pl. 1, fig. 11)

1962 Globoquadrina praedehiscens Blow and Banner: pp. 116-117, pl. 15, figs. Q, R, S.

Globoquadrina sp. cf. sp. 1 (Jenkins \& Orr, 1972) (Pl. 2, figs. 7-8)

1972 cf. Globigerina sp. 1 Jenkins \& Orr: p. 1085, pl. 3, figs. 4-6 (not figs. 1-3).

Remarks. Several samples from the lower part of Zone P21

\section{Explanation of Plate 2}

Fig. 1. Globigerina mangulisuturalis Bolli. Ventral view. Zone P21. (x115).

Figs. 2, 3. Paragloborotalia mopima (Bolli). Ventral and dorsal views. Zone P20. (x85).

Fig. 4. Tenuitellinata mangustiumbilicata (Bolli). Ventral view. Zone P21. (x115).

Fig. 5. Globigerina praeturritilina Blow \& Banner. Peripheral view. Zone P20. (x115).

Fig. 6. Globigerina gortanii (Borsetti). Peripheral view. Zone P21. (x85).

Figs. 7-8. Globoquadrina sp. cf. sp. 1 (Jenkins \& Orr). Ventral views. Zone P21. (x115).

Fig. 9. Globigerina officinalis Subbotina. Ventral view (ultimate chamber missing). Zone P20. (x115).

Figs. 10-11. Globigerina corpulenta Subbotina. Ventral and dorsal view. Zone P21 (x85). 

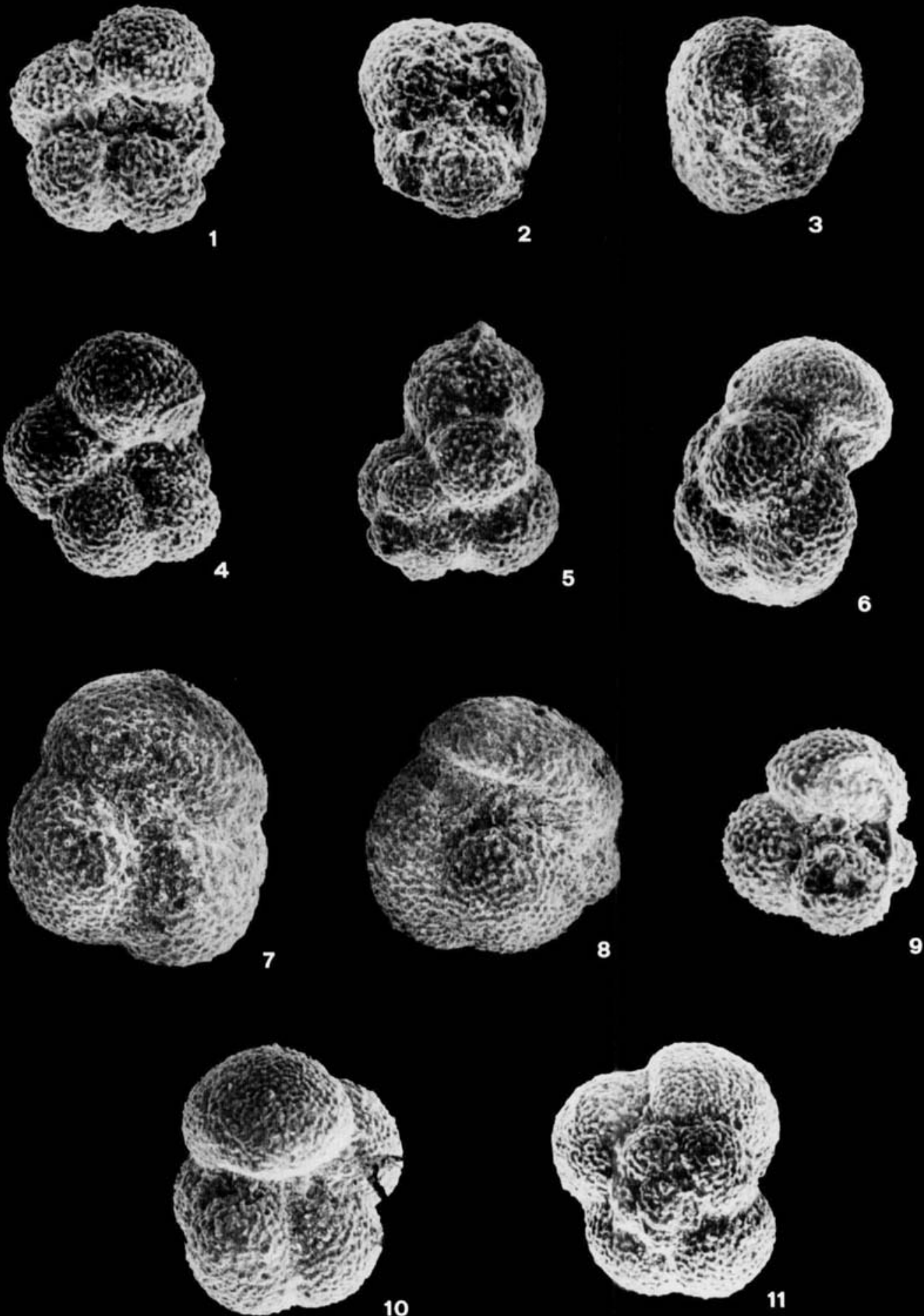
yielded specimens well corresponding to those figured by Jenkins and Orr (1972). Both morphotypes are mainly characterized by the same sculpture of the test surface, the loosely coiling and the wide, low arched aperture. They are both from the same biostratigraphic level.

Globoquadrina tripartita tapuriensis (Blow \&Banner, 1962) 1962 Globigerina tripartita tapuriensis Blow \& Banner: p.97, pl. 10, figs. H-K.

Remarks. The taxon occurs with rare specimens. G.tapuriensis appears to have become extinct much earlier at low latitude areas (within Zones P19-P20 according to Jenkins \& Orr, 1972; Bolli \& Saunders, 1985) than in the studied material.

Globoquadrina tripartita tripartita (Kock, 1926) 1926 Globigerina bulloides var. tripartita Kock: p. 746, fig. 21.

Globoquadrina sellii Borsetti, 1959

1959 Globoquadrina sellii Borsetti: p. 209, pl. 1, fig. 3.

Genus Globorotalia Cushman, 1927

"Globorotalia"siakensis Le Roy, 1939

1939 Globorotalia siakensis Le Roy: pp. 39-40, pl. 3, figs. 30-31. Remarks. Kennett \& Srinivasan (1983) included this species in their new subgenus Jenkinsella, which represents a largely Neogene lineage including species such as "G." mayeri and "G."acrostoma. The taxon is also frequently assigned to the genus Paragloborotalia (Cifelli, 1982) a prevailing Palaeogene lineage, although this attribution remains somewhat controversial. Loeblich \& Tappan (1987), for instance, regard Jenkinsella as a junior synonym of Paragloborotalia, perhaps without adequate considerations on the phyletic history of the two foraminiferal stocks.

“Globorotalia" sp. cf. siakensis Le Roy, 1939 (Pl. 1, figs. 7-9)

1939 cf. Globorotalia siakensis Le Roy: pp. 39-40, pl. 3, figs. 30-31. Remarks. This taxon is present with scattered specimens throughout the section. It well corresponds with the specimens identified by Jenkins \& Orr (1972) as Globorotalia siakensis (pl. 32, figs. 1-3). Compared to "G." siakensis, the Eptahorion specimens possess a reduced number of chambers in the last whorl, narrower umbilical area and less developed apertural arch.

Genus Globorotaloides Bolli, 1957

Globorotaloides suteri Bolli, 1957

1957 Globorotaloides suteri Bolli: p. 117, pl. 27, figs. 9-13.

Genus Paragloborotalia Cifelli, 1982

Paragloborotalia nana (Bolli, 1957)

1957 Globorotalia opima nana Bolli: p. 118, pl. 28, fig. 3.

Paragloborotalia opima(Bolli, 1957)

(Plate 2, figs. 2, 3)

1957 Globorotalia opima opima Bolli: p. 117, pl. 28, figs. 1-2.

Genus Tenuitella Fleisher, 1974

Tenuitella postcretacea (Myatliuk, 1950)

1950 Globigerina postcretacea Myatliuk: p. 280, pl. 4, fig. 3.

Remarks. A single specimen of this taxon comes from sample
14. The species can be easily allocated to the genus Tenuitella by its small test and smooth wall surface, according to the original diagnosis of Fleisher (1974).

\section{Genus Tenuitellinata Li, 1987 \\ Tenuitellinata angustiumbilicata (Bolli, 1957) \\ (Pl. 2, fig. 4)}

1957 Globigerina ciperoensis angustiumbilicata Bolli: p. 109, pl. 22, figs. 12-13.

Remarks.The thin and pustulate wall surface and the intraumbilical aperture allow the assignment of the species to the genus Tenuitellinata, recently described by Li (1987). He designated this taxon as type species of the new genus. In addition to the differences linked to the morphologic criteria, $T$. angustiumbilicata differs from $G$. angulisuturalis (and from other taxa of the ciperoensis group) in the wall structure, being spinose in the latter species. From this evidence the species can be seen as giving rise from the tenuitellid plexus. Thus, it is clearly distinct from the $G$. ciperoensis phylogenetic history. Relationships between T. angustiumbilicata, together with other tenuitellids, and the bullate Neogene Globigerinita were recently proposed (Fordham, 1986; Li, 1987).

\section{ACKNOWLEDGEMENTS}

Field work in Greece during summer 1985 was carried out by the writer, Luca Masini and Gian Gabriele Ori. Thanks go to Isabella Premoli Silva (University of Milan) for her helpful comments on the manuscript; to Paolo Ferrieri for the SEM micrographs and to Ottavio Mattei and Renato Lambertucci who drafted the figures. George Nagy revised the English text.

Manuscript received July 1990

Manuscript accepted February 1992

\section{REFERENCES}

Agip 1982. Foraminiferi Padani (Terziario e Quaternario). Atlante iconografico e distribuzione stratigrafica. 52 pls.

Baumann, P. 1970. Mikropalaontologische und stratigraphische Untersuchungen der obereozanen-oligozanen Scaglia im Zentralen Apennin (Italien). Ecl. geol. Helv', 63, 1133-1211.

Beckmann, J.P., Bolli, H.M., Perch-Nielsen, K., Proto Decima, F., Saunders,J.B.\& Toumarkine, M. 1981. Major calcareous nannofossil and foraminiferal events between the Middle Eocene and Early Miocene. Palaeogeogr., Palaeoclim., Palaeoccol., 36, 155-190.

Berggren, W.A. \& Phillips, J.D. 1971. Influence of continental drift on the distribution of the Tertiary benthonic foraminifera in the Caribbean and Mediterranean region. In: Gray, C.(Ed.), Symposium on the Geology of Libyn, Tripoli, 263-299.

Bermudez, P.J. 1960. Contribucion al estudio de las Globigerinidea de la region Caribe-Antillana (Paleocene-Reciente). Bol. Geol. (Venezuela), Spec. Publ. 3 (3rd Venez. Geol. Congr., Caracas, 1959, Mem. 3), 1119-1393.

Blow, W.H. 1959. Age, correlation and biostratigraphy of the upper Tocuyo (San Lorenzo) and Pozon Formations, eastern Falcon, Venezuela. Bull. Amer. Paleont., 39, 67-251.

Blow, W.H. 1969. Late Middle Eocene to Recent planktonic foraminiferal biostratigraphy. In: Bronnimann, R. \& Renz, H.H. (Eds), Proc. 1st Inter. Conf. Plankt. Microfossils, Gonern, 1, 199-421.

Blow, W.H. \& Banner, F.T. 1962. The Mid-Tertiary (Upper Eocene to Aquitanian) Globigerinaceae. In: Eames, F.E. et al. (Eds), Fundamentals of Mid-Tertiary stratigraphical correlation, 61-151, 
Cambridge Univ. Press.

Boersma, A. 1986. Eocene/Oligocene Atlantic paleo-oceanography using benthic foraminifera. In: Pomerol, C. \& Premoli Silva, I. (Eds), Terminal Eocene events, 225-236, Elsevier.

Bolli, H.M. 1954. Note on Globigerina concinna Reuss, 1850. Contr. Cushman Found. Foram. Res., 5, 1-3.

Bolli, H.M. 1957. Planktonic foraminifera from theOligocene-Miocene Cipero and Lengua Formations of Trinidad, B.W.I. Bull. U.S. Nat. Museum, 215, 97-123.

Bolli, H.M. 1966. Zonation of Cretaceous to Pliocene marine sediments based on planktonic foraminifera. Bol. Inf. Asoc. Venez. Geol. Miner. Petr., 9, 3-32.

Bolli, H.M., Loeblich, A.R. Jr. \& Tappan, H. 1957. Planktonic foraminiferal families Hantkeninidae, Orbulinidae, Globorotaliidae and Globotruncanidae. Bull. U.S. Nat. Museum, 215, 3-50.

Bolli, H.M. \& Saunders, J.B. 1985. Oligocene to Holocene low latitude planktic foraminifera. In: Bolli,H.M., Perch-Nielsen, K. \& Saunders, J.B. (Eds), Plankton Stratigraphy, 155-262, Cambridge Univ. Press.

Borsetti, A.M. 1959. Tre nuovi foraminiferi planctonici del Oligocene piacentino. Giorn. Geol., 27, 205-212.

Brunn, J.H. 1956. Contribution a l'etude geologique du Pinde septentrional et d'une partie de la Macedonie occidentale. Ann. Geol. Pays Hellen., 7, 1-358.

Chapronière, G.C.H. 1981. Late Oligocene to Early Miocene planktic foraminiferida from Ashmore Reef No. 1 well, northwest Australia. Alcheringa, 5, 103-131.

Cifelli, R. 1982. Early occurrences and some phylogeneticimplications of spiny, honeycomb textured planktonic foraminifera. Jour. Foram. Res., 12, 105-115.

Cita, M.B. \& Zocchi, M. 1978. Distribution patterns of benthic foraminifera on the floor of the Mediterranean Sea. Ocean. Acta, 1, 445-462.

Cushman, J.A. \& Bermudez, P.J. 1937. Further new species of foraminifera from the Eocene of Cuba. Contrib. Cushman Lab. Foram. Res., 13, 1-29.

Desprairies, A. 1979. Étude sedimentologique des formations à caractère flysch et molasse, Macedonie, Epire (Grèce). Mem. Soc. Géol. France, 136, 1-80.

Douglas, R.G. 1973. Benthonic foraminiferal biostratigraphy in the central north Pacific. In: Winterer, E.L. et al. (Eds), Init. Repts Deep Sea Drill. Proj., 17, 607-671.

Fleisher, R.L. 1974. Cenozoic planktonic foraminifera and biostratigraphy, Arabian Sea Deep Sea Drilling Project, Leg 23A. In: Weser, R.B. et al. (Eds), Init. Repts Deep Sea Drill. Proj., 23, 1001-1072.

Fordham, G.B. 1986. Miocene-Pleistocene planktic foraminifers from D.S.D.P. sites 208 and 77, and phylogeny and classification of Cenozoic species. Univ. Chicago, Evolutionary Monographs 6, 200pp.

Glaessner, M.F. 1937. Planktonforaminiferen aus der Kreide und dem Eozaen und ihre stratigraphische Badeutung. Moscow Univ. Lab. Paleont., Studies Micropaleont., 1, 27-46.

Haq, B.U., Hardenbol, J. \& Vail, P.R. 1987. Chronology of fluctuating sea levels since Triassic. Science, 235, 1156-1167.

Hedberg, H.D. 1937. Foraminifera of the Middle Tertiary Carapita Formation of northeastern Venezuela. Jour. Paleont., 11, 661-697.

Hofmann, W. 1967. Untersuchungen an der Gattung Bolivina (Foraminifera) im Oligozan und Miozan der ostbayerischen Molasse. Geol. Bavarica, 57, 121-204.

Howe, H.V. \& Wallace, W.E. 1932. Foraminifera of the Jackson Eocene at Danville Landing on the Ouachita, Catahoula Parish, Louisiana. Bull. Louisiana Dept. Cons. Geol., 2, 18-79.

IGRS-IFP. 1966. Étude géologique de l'Epire (Grèce nord occidentale), 306pp., Editions Technip.

Jenkins, D.G. 1960. Planktonic foraminifera from Lakes Entrance oil shaft, Victoria, Australia. Micropaleont., 6, 345-371.

Jenkins, D.G. 1964. A new planktonic foraminiferal subspecies from the Australasian Lower Miocene. Micropaleont., 10, 72.

Jenkins, D.G. \& Orr, W.N. 1972. Planktonic foraminiferal biostratigraphy of the Eastern Equatorial Pacific - DSDP Leg 9. In: Hays, J.D. et al. (Eds), Init. Repts Deep Sea Drill. Proj., 9, 1059-1193.

Keller, G. 1983. Paleoclimatic analyses of the Middle Eocene through Oligocene planktic foraminiferal faunas. Palaeogeogr., Palaeoclim., Palaeoecol., 43, 73-94.

Kennett, J.P. 1978. The development of planktonic biogeography in the southern ocean during the Cenozoic. Mar. Micropaleont., 3, 301345.

Kennett, J.P. \& Srinivasan, M.S. 1983. Neogene planktonic foraminifera. A phylogenetic atlas. Hutchinson Ross Publishing Company, 265pp.

Kock, R.E. 1926. Mitteltertiare Foraminiferen aus Bulongan, OstBorneo. Ecl. geol. Helv., 19, 722-751.

Le Roy, L.W. 1939. Some smaller foraminifera, ostracoda and otoliths from the Neogene ("Miocene") of the Rokan-Tapanoeli area, central Sumatra. Natuurk. Tijdschr. Neder.-Indie, 99, 215-296.

Lindenberg, H.G. 1965. Die Bolivinen (Foram.) der Haring Schichten. Mikropalaontologische Untersuchungen im Alttertiar des Unterinntal-Gebietes. Boll. Soc. Paleont. Ital., 4, 64-160.

Li, Q. 1987. Origin, phylogenetic development and systematic taxonomy of the Tenuitella plexus (Globigerinitidae, Globigerininina). Jour. Foram. Res., 17, 298-320.

Loeblich, A.R. Jr. \& Tappan, H. 1987. Foraminiferal genera and their classification. Van Nostrand Reinhold Company, 2 vols, 1200pp. 847 pls.

Miller, K.G. 1983. Eocene-Oligocene paleoceanography of the deep Bay of Biscay: benthic foraminiferal evidence. Mar.Micropaleont., 7, 403-440.

Molina, M.E. 1979. Oligoceno-Mioceno inferior por medio des foraminiferos planctonticos en el sector central de las Cordilleras Beticas (Espana). Tesis doct. Publ. Univ. Granada y Zaragoza, 342pp.

van Morkhoven, F.P.C.M., Berggren, W.A. \& Edwards, A.S. 1986. Cenozoic cosmopolitan deep water benthic foraminifera. Bull. Centre Rec. Expl.-Prod. Elf-Aquitaine, Mem. 11, 421pp.

Myatliuk, E.V. 1950. Stratigrafiya flishevykh osadkov severnykh Karpat v cveta dannykh fauny foraminifer. Vses Neft. NauchnoIssled. Geol. Razved. Inst. Trudy, 51, 225-287.

Ori, G.G., Masini, L. \& Barbieri, R. 1990. Stratigrafia, facies e sequenze deposizionali dei depositi torbiditici del bacino mesoellenico, Oligocene-Miocene, Grecia settentrionale. Giorn. Geol., 52, 197-219.

Pflum, C.E. \& Frerichs, W.E. 1976. Gulf of Mexico deep-water foraminifers. Cush. Found. Foram. Res., Spec. Publ. 14, 125pp.

Proto Decima, F. \& Bolli, H.M. 1978. Southern Atlantic DSDP Leg 40 Paleogene benthic foraminifers. In: Holli, H.M. et al. (Eds), Init. Repts Deep Sea Drill. Proj., 40, 783-809.

Pujos Lamy, A. 1984. Foraminifères benthiques et bathymetrie: le Cenozoique du Golfe de Gascogne. Palaeogeogr., Palaeoclim., Palaeoecol., 48, 39-60.

Sancetta, C. 1979. Paleogene Pacific microfossils and paleoceanography. Mar. Micropaleont., 4, 363-398.

Schnitker, D. 1979. Cenozoic deep water benthic foraminifers, Bay of Biscay. In: Montadert, L. et al. (Eds), Init. Repts Deep Sea Drill. Proj., 48, 377-413.

Soliman, H.A. \& Zygojannis, N. 1979a. Paleogeographic features during Oligocene-Miocene transition and their bearing on Oligocene-Miocene foraminifera in the Mesohellenic Basin, Northern Greece. Ann. Géol. Pays Hellén., 3, 1113-1122.

Soliman, H.A. \& Zygojannis, N. 1979b. On the biozonation of the Oligocene sequences by foraminifera in the South Mesohellenic Basin, Northern Greece. Proc.6th Coll. Geol. Aegean Reg., Athens, 3, 1095-1104.

Soliman, H.A. \& Zygojannis, N. 1980. Geological and paleontological studies in the Mesohellenic Basin, Northern Greece. Inst. Geol. Min. Expl., Athens, Geol. Geoph. Res., 22, 1-66. 
Stainforth, R.M., Lamb, J.L., Luterbacher, H.P., Beard, J.H. \& Jeffords, R.M. 1975. Cenozoic planktonic foraminiferal zonation and characteristics of index forms. Univ. Kansas Paleont. Contr., Art.62, 425pp.

Stainforth, R.M. \& Lamb, J.L. 1981. An evaluation of planktonic foraminiferal zonation of the Oligocene. Univ. Kansas Paleont. Contr., Paper 104, 42pp.

Steininger, F.F., Senes, J., Kleemann, K. \& Rogl, F. (Eds). 1985. Neogene of the Mediterranean Tethys and Paratethys. Stratigraphic correlation tables and sediment distribution maps. IGCP Project, 25, 1, 189pp.; 2, 532pp.

Subbotina, N.N. 1953. Iskopaemye foraminiferySSSR: Globigerinidae, Hantkeninidae, Globorotaliidae. Vses. Neft. Nauchno-Issled. Geol. Razved. Inst. Trudy, 76, 296pp. (Translated into English by Lees, E. 1971. Fossil foraminifera of the USSR, Globigerinidae, Hantkeninidae, Globorotaliidae. Collet's Ltd, 321pp.)
Sztrakos, K. 1979. La stratigraphie, paleoecologie, paleogeographie et les foraminifers de l'Oligocene du Nord-Est de la Hongrie. Cah. Micropaleont., 3, 95pp.

Sztrakos, K. 1983. Le genre Uvigerina (Foraminifère) dans le Paleogène de la Hongrie. Rev. Micropaleont., 26, 132-142.

Thomas, E. 1985. Late Eocene to Recent deep-sea benthic foraminifers from the Central Equatorial Pacific Ocean. In: Mayer, L. et al. (Eds), Init. Repts Deep Sea Drill. Proj., 85, 655-694.

Todd, R. 1957. Geology of Saipan, Mariana Islands, Pt. 3, Paleontology. U.S. Geol. Survey, Prof. Paper, 280H, 265-320.

Winkler, W. 1983. Rhabdammina-fauna: what relation to turbidites? Evidence from the Gurnigel-Schlieren Flysch. Benthos'83, 2nd Int. Symp. Benthic Foraminifera, Pau, 611-617.

Wright, R. 1978. Neogene paleobathymetry of the Mediterranean based on benthic foraminifers from DSDP Leg 42A. In: Hsu, K et al. (Eds), Init. Repts Deep Sea Drill. Proj., 42, 837-846. 